\title{
Interconnection of Religious Education and Modern Science in Islamic Religious Learning
}

\author{
Firman Mansir \\ (Universitas Muhammadiyah Yogyakarta, Jl. Brawijaya, Daerah \\ Istimewa Yogyakarta, Indonesia) \\ firmanmansir@umy.ac.id
}

\begin{abstract}
This study discusses the relationship between Islamic education and science at Madrasah Ibtidaiyah, an essential educational institution. Islamic religious education directed at schools, especially Madrasah Ibtidaiyah, is a procedure to enforce the basics of faith and devotion to students. Strengthening science and technology allows students to do various things to realize multiple needs in their lives. This study aims to determine the relationship between Islamic education and modern science in madrasas. This study uses a qualitative method. The data collection technique used is a literature study. The data study technique uses data reduction, presentation, and conclusion drawing. The results of this study are the integrated model is a model of integrating science and Islamic religious education (PAI) in the learning process. The existence of a link between the relationship between Islamic Religious Education and science at madrasah can provide new insights for students about the importance of science and religion in religious and social life.
\end{abstract}

Keywords: Interconnection, Religious Education, Modern Science, Learning.

\section{Introduction}

It should be recognized that Islam is a religion revealed by Allah SWT through the angel Gabriel who conveyed His revelations to His chosen creatures. If it is related to education, Islam provides insight and horizons regarding various sources of knowledge that study Islam. As Prophet Muhammad SAW was sent to share the symbols of Islam and strengthen the suitable activities, even teachings that mislead his followers can also be overcome (Rerung, Sinon, \& Widyaningsih, 2017).

Science and religion are interconnected and complete knowledge. Al-Qur'an and Hadith are sources of knowledge (Nata, 2013). However, some scientists argue about religion and science, each 
standing on its portion. This is because the field of science is fixated on empirical data to determine the truth of the science. At the same time, religion accepts abstract and is not only based on belief (Karni, 2009). Religion and Science have the same scientific mission. Thus, they must coexist independently of one another.

The curriculum needs to contain Islamic values as important in school activities (Suprayogo, 2007). It means that curriculum design must combine qauliyah and kauniyah values in curriculum building. It does not only implement studying Islamic material, which in its orientation is 'Ulum Syar'iyah (fiqh, worship, morality, and aqidah), but also a religious view. Islam can provide the knowledge, behaviour, and attitude needed in the context of life today and the future (Miftah, 2017). Furthermore, when viewed from the religious aspect, classification, and curriculum structuring, it states that there is a scientific dichotomy between spiritual lessons in madrasas in the form of History of Islam, Fiqh, Aqidah morality, and general classes in schools in the form of social studies, science, mathematics (Ikhwan, 2014).

The religious content is only found in religious subjects, while the general issues do not have religious content entirely. However, in an integrated learning system, there is no classification between spiritual science and science, although there is a classifier of science into social sciences and exact sciences. Yet, type is carried out on the objects of the sciences themselves, not classification in terms of position and use (Fiteriani, 2014). This means that science should also include religious sciences.

Although the material is objectively different, it has a relationship and attachment to religion. The knowledge obtained by experts has destroyed itself because the experts do not understand the science of religion. Thus, it is not embedded in them. Therefore, religious learning is obliged to increase the integration of faith and science. Thus knowledge is more equitable (Mansir, 2020). If it is seen and observed education in madrasah ibtidaiyah, it should involve a new culture that combines religion and science in upholding religious values or madrasa identity to strengthen general knowledge. In this case, the integration of a scientist needs to receive the main concern along with religious and scientific education (Syam, 2017).

This is conducted none other than to foster the faith and piety of students by exploring various theories of science. It directs to educate students. However, it is expected that they will balance religion with other knowledge. Thus, it can be implemented in real life (Naziah, 
2018). When the education system begins to be improved, it can be channelled to the education system. It means that a country will become superior, that cares about the equipment that will lead it to superior civilization. The device has a complete personality and character of nationalism. To achieve this, proper education is needed for the social environment and its surroundings to combine the elements contained in it into a form of good integration.

\section{Method}

This research used a qualitative research type and a literature study method by combining data from books and journals related to the issues. The first procedure is to determine the formulation of the problem and what problems will be studied. Following the type of qualitative research, the researcher used the literature study method. Therefore, the researcher searched selected or reduced sources and facts based on library data in journals or books related to research. The data were collected based on library data in journals or books. The researchers then concluded from sources related to the study. The data collection technique used Library Research, namely researching finding and reducing library data in journals or books related to research. Hence, researchers could obtain theoretical data (Ikhwan, 2021).

\section{Result and Discussion}

Islamic Religious Education is a conscious effort in education. It can direct the formation of one's morals following religious norms. In addition, students can also understand, recognize, believe, appreciate, have a noble character, and be pious in practising religious teachings based on Al-Qur'an and Hadith by carrying out learning (Mz, 2018). Islamic Education also has a goal as a business that can direct and guide humans to become human beings who are pious and have faith in Allah SWT.

Education in Indonesia is currently in a low place. Its development process still has problems, namely the difficulty of students in understanding the value of learning, which causes when students apply it, they experience a mismatch between theory and the natural world (Mansir, 2021). The emergence of western culture in Indonesia has resulted in not all Islamic education in schools that prioritize religion but has been mixed with western education. It is 
because western education is very influential in the world of education. Hence, Islamic education bases moral formation to avoid western influences (Anwar, 2021).

Islamic Education needs to be closely tied to the social-praxis dimension because this education has a social effect so that it is always perceptive of social reality. It is necessary to develop the thoughts of the individual. It is not limited to theoretical-conceptual thinking (Nasiruddin, 2013). In the development of science, there is an education system, informal, formal, and non-formal education, which can transfer knowledge in all aspects. Likewise, Madrasas are moving to create learning integration between religion and science. This is where the theory of the integration of science and religion emerges. Therefore, Komarudin Hidayat stated that religion and science are the cultural pinnacles that have ushered in the birth of a global society.

According to Imam Suprayogo, madrasas must meet the community's needs who want their children to become excellent and bright figures. In this case, the development of education in madrasas must be proven in the religious learning process to form the character. In addition, Abuddin Nata explained that a good, superior, quality and personal education would make people more competent. Therefore, education is a practical process between students and educators to grow students' attitudes and apply them in real life.

However, science can also be defined as a system for studying the universe through experiments and observations in the form of objective evidence. Science is a verse of Allah in a qauniyah that emphasizes more on matters related to natural events and natural preservation. There are several science functions; First, science can help humans think systematically. Second, science can explain natural phenomena that are around. Third, science can provide instructions regarding natural laws. Thus, natural phenomena that occur will follow these natural laws. For example, when a volcanic eruption occurs before the outbreak, the geophysics and meteorology services have known and predicted the explosion.

\section{The Nature of Islamic Education}

It was found in the syllabus/Outlines of the Teaching Program (GBPP) of Islamic Religious Education at the SD, SLTP, SMU/K, and Madrasas levels. They are sustainable by including the development of Islamic religious education, such as increasing trust, awareness, appreciation, and the twists and turns of participants' lives in education about Islam. Thus, the goals are achieved to prepare people 
who believe and are devoted and have the noble character to Allah SWT in every personal, social, national, and state activity. Based on the objectives, it can be concluded that Islamic Education in schools and madrasah are basically to foster students' basic faith and devotion to Allah SWT.

Therefore, it is necessary to develop the scope of Islamic Education that consists of harmony, harmony, and balance. Those aspects greatly influence human interaction with the environment. Therefore, there are seven main elements of Islamic religious education material such as belief, the practice of al-Qur'an, adabi/culture, law, muamalah, and history. Furthermore, the learning process focuses on developing three aspects in students, namely Bloom's Taxonomy, including cognitive aspects, affective aspects, and psychomotor aspects. We need to know that integrating science and religion does not mean only unifying religious knowledge and general science but also making Islamic teachings a paradigm of social science. Islam is a perspective and a guardian of every scientific act/work.

Integrating science and religion is essential to ensure that Islamic teachings are the source of inspiration for all knowledge (Batubara, 2018). According to Al-Kailani in the study of Islamic education, it looks like it still has a descriptive, normative, and adoptive pattern along with the "West-centric" or vice versa, "Salaf-centric" (Al-Kailani, 1988). Religious traditions that adhere to kaffah Islam have a wealth of affluent and sophisticated scholars, and these figures are synthetic and creative in Islam. This difference causes its complications. This is because the new education in Islam derived from Western life organizations has a value context in its internal structure and provisions. However, Islamic education has experience adopting methods to Greek philosophy and science.

According to Omar Muhammad al-Toumy al-Syaibani, the purpose of education is to improve personal attitudes towards activities through learning as a primary activity in society. This relates to teaching and learning as a science, skill, profession, and actor in society. The purpose of education is in line with Azyumardi Azra's study. Education is preparing the younger generation to carry out in life and the vision and mission effectively and efficiently. Teaching is teaching a knowledge transfer process, not a change in value but character creation in all fields. Integrating religion and science, namely Islamic education, is now an education system such as Inter-discipline Sciences in Islam. With the new teaching system, the curriculum 
provided is expected to be a form of unity and systematic unity between revelation and science.

\section{The Integration of Science in Madrasas in the Education Context}

The relation between Islamic education and science at the madrasah combines learning with a single theme to facilitate teaching and learning activities for students. Each problem can not only be explained in one field of study but also have interrelationships between fields and subjects.

This model is also an attempt to erode the scientific dichotomy that occurs in education. Besides, it can also answer students' curiosity about the importance of learning science based on the value of faith in Allah SWT because they have aspects of practising religious values in real life. "The integration of PAI and science provides aspects of the practice of Islamic religious values in everyday life for students" (Siregar, Zahra, \& Bujuri, 2019).

In this case, what is meant by the relationship between religious education and science is not only conveying PAI material interspersed with science material but what is meant by the relationship between religious education. In addition, science is when educators deliver Islamic Education material associated with scientific facts. Because today's students think more deeply, they always associate religious education material with real life. For example, we link the Al-Quran and scientific facts to the Isra 'Mi'raj of the Prophet Muhammad SAW. Isra 'mi'raj is not a story of space travel. Astronomical aspects do not exist in the study of Isra 'mi'raj. However, Isra 'mi'raj disturbs the curiosity of the human mind to seek an explanation of science. Aspects of aqidah and worship are integrated with scientific aspects in discussing Isra 'mi'raj. Isra' Mi'raj's scientific inspiration encourages us to think about integrating science into aqidah and worship (Chanifudin \& Nuriyati, 2020).

The implications of the model in learning are in the form of; First, while teaching and learning, educators use parables. For example, students are trained to develop their creative imagination by explaining roses. Students demonstrate the petal representing various cultures, mythology, science, spiritual approaches, and philosophies centred on flowers. Roses grow based on human experience, and the thorns are models and systems of thought built from human experience and students are invited to understand that experience. They will grow thinking about the basic assumption that science and 
religion can and should work together to produce a richer understanding of our world (Arifudin, 2016).

With this parable, we can teach students to learn to integrate science and religion with the students' understanding. They will understand that science and religion are interrelated. In addition, students will know that the model of integration of science and religion must be seen in reality, not only theoretically. Using the builtin inquiry model in the learning process reinforces the search program and describes the relationship between objects and circumstances (Mansir, Purnomo, \& Tumin, 2020). This form of guided inquiry learning can make students more responsible and independent because this inquiry encourages students to seek deeper explanations by using scientific skills to investigate problems.

Therefore, the implications of this model in Islamic Education learning are: First, when Islamic Education learning takes place, the educator uses parables so that students can understand the meaning of each parable. Second, Islamic Education learning materials include theoretical, historical, case, science, technology, and practical. The third is the inquiry model that describes the object with the state. With the integration model of science and religious education, it is helpful to make it easier for educators to integrate spiritual and scientific education. This model can also improve students' experience because they unwittingly understand and learn concepts that have been studied directly.

\section{Conclusion}

So far, Islamic Education studies have only studied religious studies. They are not related to science. The Islamic Education learning should integrate the "Qauniyah" verse and the "Qauliyah" verse. Islamic Education material in schools is the verse "al-Qur'an" and other things related to the surrounding environment, namely the human environment or the natural environment. Thus, "Hablu-min Allah" and "Hablu-min al-nas" were created. There is an integration between Islamic Religious Education and modern science in madrasas. Science explains the occurrence of natural phenomena. In this case, what is meant by the relationship between religious education in madrasas and science is that it does not only convey Islamic Education material interspersed with science material, but what is meant by the relationship between religious education and science is when teachers deliver Islamic Education material. Scientific facts link it. The 
relationship between Islamic education and science at the madrasah links or combines learning with a single theme. Thus, it can facilitate teaching and learning activities for students. Hence, a common thread can be drawn that Islamic religious education delivered in schools and especially in madrasah Ibtidaiyah is basically to grow the foundation of faith and piety of students towards Allah SWT and can implement it in everyday life.

\section{Bibliography}

Al-Kailani, M. I. (1988). Falsafat al-Tarbiyah al-Islamiyah. Makkah: Maktabah Hadi.

Anwar, S. (2021). Pendidikan Karakter: Kajian Perspektif Tafsir fi Zilalil Qur'an. Tulungagung: STAI Muhammadiyah Tulungagung.

Arifudin, I. (2016). Integrasi Sains Dan Agama serta Implikasinya terhadap Pendidikan Islam. Jurnal Adukasia Islamika, 1(1).

Chanifudin, \& Nuriyati, T. (2020). Integrasi Sains dan Islam dalam Pembelajaran. Asatiza, 1(2), 212-229.

Fiteriani, I. (2014). Analisis Model Integrasi Ilmu dan Agama dalam Pelaksanaan Pendidikan di Sekolah Dasar Islam Bandar Lampung. TERAMPIL: Jurnal Pendidikan Dan Pembelajaran Dasar, 1(2), 150-179.

Ikhwan, A. (2014). Integrasi Pendidikan Islam (Nilai-Nilai Islami dalam Pembelajaran). Ta'allum: Jurnal Pendidikan Islam, 2(2), 179194.

Ikhwan, A. (2021). Metode Penelitian Dasar (Mengenal Model Penelitian dan Sistematikanya). Tulungagung: STAI Muhammadiyah Tulungagung.

Karni, A. S. (2009). Etos studi kaum santri: wajah baru pendidikan Islam. PT Mizan Publika.

Mansir, F. (2020). Diskursus Sains dalam Kurikulum Pendidikan Agama Islam di Sekolah dan Madrasah Era Digital. Kamaya: Jurnal Ilmu Agama, 3(2), 144-157.

Mansir, F. (2021). Aktualisasi Pendidikan Agama dan Sains dalam Character Building Peserta Didik di Sekolah dan Madrasah. JPAI: Jurnal Pendidikan Agama Islam, 7(2).

Mansir, F., Purnomo, H., \& Tumin, T. (2020). Penerapan 
Pembelajaran Pendidikan Agama Islam Berbasis Sains Budaya Lokal Di Sekolah Dan Madrasah. TARBAWY : Indonesian Journal of Islamic Education, 7(1), 70-79. https://doi.org/10.17509/t.v7i1.23478

Miftah, M. (2017). Model Integrasi Sains dan Agama dalam Pendidikan Nasional. Jurnal Penelitian, 14(2), 233-246.

Mz, S. R. (2018). Akhlak Islami Perspektif Ulama Salaf. Edukasi Islami: Jurnal Pendidikan Islam, 7(01), 67-100.

Nasiruddin. (2013). INTEGRASI SAINS DAN AGAMA DALAM PENDIDIKAN ISLAM. IV(2).

Nata, A. (2013). Pemikiran Pendidikan Islam dan Barat. Jakarta: Raja Grafindo Persada.

Naziah, W. S. A. (2018). INTEGRASI AGAMA DAN SAINS DALAM PEMBELAJARAN PENDIDIKAN AGAMA ISLAM DI SEKOLAH MENENGAH ATAS NEGERI 3 MALANG. University of Muhammadiyah Malang.

Rerung, N., Sinon, I. L. S., \& Widyaningsih, S. W. (2017). Penerapan model pembelajaran problem based learning (PBL) untuk meningkatkan hasil belajar peserta didik SMA pada materi usaha dan energi. Jurnal Ilmiah Pendidikan Fisika Al-Biruni, 6(1), 47-55.

Siregar, M., Zahra, D. N., \& Bujuri, D. A. (2019). INTEGRASI MATERI PENDIDIKAN AGAMA ISLAM DALAM ILMUILMU RASIONAL DI SEKOLAH MENENGAH ATAS ISLAM TERPADU. Al-Tadzkiyyah: Jurnal Pendidikan Islam, 10(2), 183201.

Suprayogo, I. (2007). Quo Vadis Madrasah, Gagasan, Aksi dan Solusi Pembangunan Madrasah. Yogyakarta: Hikayat.

Syam, A. R. (2017). Urgensi Budaya Organisasi Untuk Pengembangan Lembaga Pendidikan Islam. Educan: Jurnal Pendidikan Islam, 1(2). 